\title{
Sleep quality and COVID-19 outcomes: the evidence-based lessons in the framework of predictive, preventive and personalised (3P) medicine
}

\author{
Kneginja Richter ${ }^{1,2,3} \cdot$ Stefanie Kellner ${ }^{2} \cdot$ Thomas Hillemacher $^{1} \cdot$ Olga Golubnitschaja $^{4}$
}

Received: 7 May 2021 / Accepted: 12 May 2021 / Published online: 8 June 2021

(c) The Author(s) 2021

\begin{abstract}
Sleep quality and duration play a pivotal role in maintaining physical and mental health. In turn, sleep shortage, deprivation and disorders are per evidence the risk factors and facilitators of a broad spectrum of disorders, amongst others including depression, stroke, chronic inflammation, cancers, immune defence insufficiency and individual predisposition to infection diseases with poor outcomes, for example, related to the COVID-19 pandemic. Keeping in mind that COVID-19-related global infection distribution is neither the first nor the last pandemic severely affecting societies around the globe to the costs of human lives accompanied with enormous economic burden, lessons by predictive, preventive and personalised (3P) medical approach are essential to learn and to follow being better prepared to defend against global pandemics. To this end, under extreme conditions such as the current COVID-19 pandemic, the reciprocal interrelationship between the sleep quality and individual outcomes becomes evident, namely, at the levels of disease predisposition, severe versus mild disease progression, development of disease complications, poor outcomes and related mortality for both - population and healthcare givers. The latter is the prominent example clearly demonstrating the causality of severe outcomes, when the long-lasting work overload and shift work rhythm evidently lead to the sleep shortage and/or deprivation that in turn causes immune response insufficiency and strong predisposition to the acute infection with complications. This article highlights and provides an in-depth analysis of the concerted risk factors related to the sleep disturbances under the COVID-19 pandemic followed by the evidence-based recommendations in the framework of predictive, preventive and personalised medical approach.
\end{abstract}

Keywords Predictive preventive and personalised medicine (PPPM/3PM) $\cdot$ COVID-19 $\cdot$ SARS-CoV-2 $\cdot$ ICU $\cdot$ Sleep quality · Sleep duration · Sleep disturbance and deprivation · Sleep-wake rhythm · Insomnia · Depression · Anxiety · Gender · Pneumonia $\cdot$ Disease progression · Patient stratification · Individual outcomes $\cdot$ Complications $\cdot$ Modifiable risk factors · Risk assessment · Shift workers · Healthcare givers · Melatonin · Treatment · Drug · Comorbidities · Immune response $\cdot$ Anti-inflammation $\cdot$ Education $\cdot$ Health policy

Kneginja Richter

kneginja.richter@klinikum-nuernberg.de

Olga Golubnitschaja

olga.golubnitschaja@ukbonn.de

Stefanie Kellner

Stefanie.Kellner@gmx.net

Thomas Hillemacher

Thomas.Hillemacher@klinikum-nuernberg.de

1 Outpatient Clinic for Sleep Disorders, University Clinic

for Psychiatry and Psychotherapy, Paracelsus Medical

University Nuremberg, 90419 Nuremberg, Germany
2 Faculty for Social Work, Technical University of Applied Sciences Nuremberg Georg Simon Ohm, 90489 Nuremberg, Germany

3 Faculty for Medical Sciences, University Goce Delcev Stip, 2000 Stip, North Macedonia

4 Predictive, Preventive and Personalised (3P) Medicine, Department of Radiation Oncology, University Hospital Bonn, Rheinische Friedrich-Wilhelms-Universität Bonn, 53127 Bonn, Germany 


\section{Preamble}

Keeping in mind that COVID-19-related global infection distribution is neither the first nor the last pandemic severely affecting societies around the globe to the costs of human lives accompanied with enormous economic burden, lessons by predictive, preventive and personalised medical (PPPM/3PM) approach are essential to learn and to follow being better prepared to defend against global pandemics. To this end, 3PM knowledge towards the COVID-19 pandemic is regularly updated in the literature $[1,2]$. Unique research data towards individual outcomes in COVID-19-affected patient cohorts accompanied by potent predictive and preventive approaches have been presented and acknowledged as a great contribution of $3 \mathrm{P}$ medicine to the global challenge by COVID-19 [3-5].

This article focused on the comprehensive sleep quality impacts, follows the series of publications presenting valuable 3PM lessons towards the COVID-19 relevant knowledge. Sleep quality plays a pivotal role in maintaining physical and mental health. In turn, sleep shortage, deprivation as well as sleep disorders are per evidence the risk factors and facilitators of a broad spectrum of disorders, among others including depression, stroke, chronic inflammation, cancer, immune defence insufficiency and individual predisposition to infection diseases with poor outcomes. Therefore, sleep deficits are highly relevant for the COVID-19 distribution and outcomes.

\section{Up-to-date facts and working hypotheses}

\section{Sleep quality and immune defence}

Sleep quality and duration have been shown to play a pivotal role in immune health. Accumulated research data clearly indicate that the immune defence is supported by sleep, whereas sleep deprivation, e.g. caused by insomnia and circadian disruption, can severely impair the immune system functionality serving therefore, as a reliable predictor $[6,7]$. During the sleep, there is an increased activity of two major subtypes of lymphocytes, which are important for the adaptive immune response and general disease prevention, namely, CD4 + "helper" $\mathrm{T}$ cells and cytotoxic CD8 + "killer" T cells. Further, a decreased activity of natural killer cells and increased production of pro-inflammatory cytokines are important for the host defence against pathogens including viral infections [7-13]. During nighttime sleep, pro-inflammatory hormones and cytokines are synchronised to facilitate the onset of an adaptive immune response. In contrast, during the daytime activity, anti-inflammatory signals, hormones and cytokines are supportive for immediate reactions towards biological and other environmental challenges [14]. Additionally, the cytokines TNF- $\alpha$ and IL-12 as well as antigen-presenting dendritic cells (DCs) show their highest activity during the night in those adhering to a normal sleep-wake routine, but also in those kept awake for $24 \mathrm{~h}$, and without change of the period ( $24 \mathrm{~h}$ ) of these rhythms. The peak time of the circadian rhythms of cortisol, epinephrine, norepinephrine and the cytokine IL-10 occurs early in the morning, around the time of awakening from night-time sleep according to the individual sleep-wake rhythm. In situations of continuous wakefulness, epinephrine displays an undefined rhythm. The peak time of the rhythm in IL-10 shifts to the night-time. Cortisol and norepinephrine show peak value rhythms similar to sleep values, which Nadir values, for both, are higher under conditions of constant wakefulness [15]. Also reduced activities of natural killer cell activity and $\mathrm{T}$ cell cytokine production in sleep-deprived subjects compared to subjects with a full night of sleep have been demonstrated [16, 17].

In this context, the relationship between sleep quality and proper immune defence functionality becomes particularly relevant for the COVID-19 pandemic outcomes. Indeed, tiredness occurs as one of the common symptoms in the early stages of COVID-19 infection, and as the diseases progresses, insomnia may emerge as an additional problem, with disturbed sleep persisting beyond the acute stage of the disease. In terms of possible long-term effects of COVID19 that exceed the typical recovery period, bundled under the term long COVID-19 or post-acute sequelae of SARS$\mathrm{CoV}-2$ infection, effects on sleep and fatigue are apparent, with sleep problems and fatigue becoming typical symptoms of long COVID-19 6 months after infection. In the context of long COVID-19, Huang et al. reported in a sample of $\mathrm{N}=1655$ that 437 individuals (26\%) showed sleep problems and fatigue or muscle weakness for 1038 individuals (63\%) [17].

Among its multi-faceted functions, sleep has been shown to regulate glucose metabolism and weight gain, both of which are acknowledged risk factors of diabetes, obesity and sleep apnoea, which in turn have been associated with a higher predisposition to disease on viral infections [18] and to severe COVID-19 disease progression [19, 20].

\section{Sleep quality and vaccination efficacy}

Considering the importance of vaccination as the primary strategy to combat viral pandemics, research data provide clear evidence towards an important role of the sleep quality in the level of vaccination efficacy [21]. It has been reported that a sufficient amount of deep and slow-wave sleep could be essential for vaccine effectiveness, as the common flu 
vaccination seems to be more effective in people who have slept well in the days preceding the vaccination [22]. Another study conducted by Lange et al. examined the role of sleep and wakefulness after receiving hepatitis A vaccination on immune responses. Results have shown that after sleep compared to wakefulness, the relative portion of the virus-specific Th cells were doubled, and the portion of Th1 cytokine-producing cells increased being important for an adaptive immune response [23]. Contextually, research data on the relationship between the sleep quality and the vaccination efficacy as well as the relevance of the impaired sleep are of great importance.

\section{Sleep quality-improving medication and COVID-19 outcomes}

While there are no specific antiviral therapeutic agents available for the COVID-19 yet [24, 25], sleep-related treatment options improving individual outcomes are available. To this end, Zhou et al. demonstrated that coronavirus infection can lead to insomnia resulting in a disturbed production of melatonin with adverse effects on the immune defence and long-term pathologic alterations in the nervous systems [26]. Based on the collected statistics, this research group hypothesised that the COVID-19 replication could be inhibited by the intake of melatonin [26].

A retrospective analysis performed by Columbia University indicated improved survival rates for the intubated ICU patients, if they were treated with melatonin [27]. To this end, Cheng et al. suggest the melatonin function in the sleep quality. In addition to its key role in regulating circadian rhythms, melatonin also modulates the immune system by inhibiting inflammation and cytokine storm as one of the most dangerous components of the COVID-19 disease [28]. Indeed, melatonin acts as anti-inflammatory and immune-modulating agent effectively boosting human immune system [22]. The review of Mohamed et al. summarises evidence on the utility of melatonin as a potential antioxidant adjuvant in COVID-19-infected individuals with diabetes and obesity, suggesting melatonin as a potent treatment option to improve COVID-19 outcomes by supporting immune health [29]. To date, there is no direct experimental evidence on the virucidal effect of melatonin; however, research data demonstrate indirect activities of melatonin as a potent antiviral helper, due to its complex anti-inflammatory, antioxidant and immunomodulatory properties [30, 31].

\section{Poor sleep quality predicts a susceptibility to infections in healthcare gives}

Healthcare givers, among the shift workers in general, are particularly susceptible to impaired sleep, due to rotating working hours and night work. Shift work, especially night work, induces a disruption of the circadian rhythm compromising the neuroimmune-endocrine homeostasis including a reduction in natural killer cells activity that has been well documented for nurses [32-37]. Sleep rhythm disturbance characteristic for the shift workers is clearly associated with a higher vulnerability to infectious diseases such as a flu [38-40], whereas reduced sleep ( $<5 \mathrm{~h})$ and poor sleep quality and/or excessive sleep ( $>9 \mathrm{~h})$ are linked with a higher risk for pneumonia [41, 42]. Further, sleep-deprived shift workers are at higher risk of respiratory infections and their severity grad $[43,44]$ that is highly relevant for the susceptibility to the COVID-19 infection and related complications. The higher risk and severity of respiratory and other infections may thus not only be associated with sleep disorders, but also to a reduced amount of slow-wave NREM sleep, which is responsible for the secretion of the cytokine IL-12 and DCs, the main precursors of Antigen-presenting cells [45, 46].

An epidemiological survey conducted in December 2019 in Wuhan revealed the highest prevalence of the poor sleep quality in $18.2 \%$ of the sample $(\mathrm{N}=7236)$ specifically for healthcare givers demonstrating compared to all other professional occupations [47]. In particular, healthcare givers working on the frontline with the acutely COVID-19 diseased individuals are directly exposed to the pathogen accompanied with the sleep imbalance and circadian disruption that makes them to a special group of risk which well-designed predictive and preventive medical approach should be applied for to protect against the health damage linked to their professional duties [48].

\section{Working hypothesis in the context of PPPM}

Based on the above presented facts, a reciprocal interrelationship has been hypothesised between the sleep quality and individual outcomes for both COVID-19 diseased and medical staff involved in the care. If being valid, this concept opens great prospects for implementing risk assessment, patient stratification, individualised prediction and targeted prevention to persons at high risk among professional and in the population linked to the well-justified educational measures.

\section{Literature search methodology}

Systematic literature search has been conducted utilising electronic data available in PubMed and Google Scholar.

Literature search investigated effects of COVID-19 on a sleep quality in hospital populations, separately considering both - the medical staff and affected patient cohorts.

Studies dedicated to the sleep quality of healthcare givers were identified by following combinations of the keywords, "COVID-19", "sleep quality", "medical staff”, "sleep 
disturbances" and "insomnia". The review was limited to published research articles written in English. Only original research articles about or literature reviews of the effects of sleep on medical staff with reported sleep assessments as outcome variables were included.

Studies dedicated to the sleep quality of the affected patients were identified by following combination of the keywords, "COVID-19", "patients", "sleep", "sleep quality" and "ICU". The review was limited to published research articles written in English. Only original research articles or literature reviews on the effects of COVID-19 on patients' sleep were included. Furthermore, only studies measuring sleep status were included.

Both search approaches are summarised in Figs. 1 and 2 , respectively.

\section{Data interpretation}

\section{Sleep quality in the COVID-19-affected patients}

Table 1 presents the collected data with corresponding interpretation towards analysed sleep quality and related aspects in the COVID-19-affected patients. Analysed studies clearly demonstrate that insomnia symptoms persist in 36-88\% of all included COVID-19 patients - the level which is significantly higher compared to the prevalence of insomnia in the general population estimated as being 10 to $40 \%$ [49, 50]. The underlying causes of the poor sleep parameters are considered as being:

1. Potentially related to early awakening by medical staff and disrupted sleep

2. Due to sedative administration

3. Due to mechanical ventilation of affected COVID-19 patients [51].
Fig. 1 Flowchart according to the PRISMA criteria on sleep disorders in COVID-19 patients

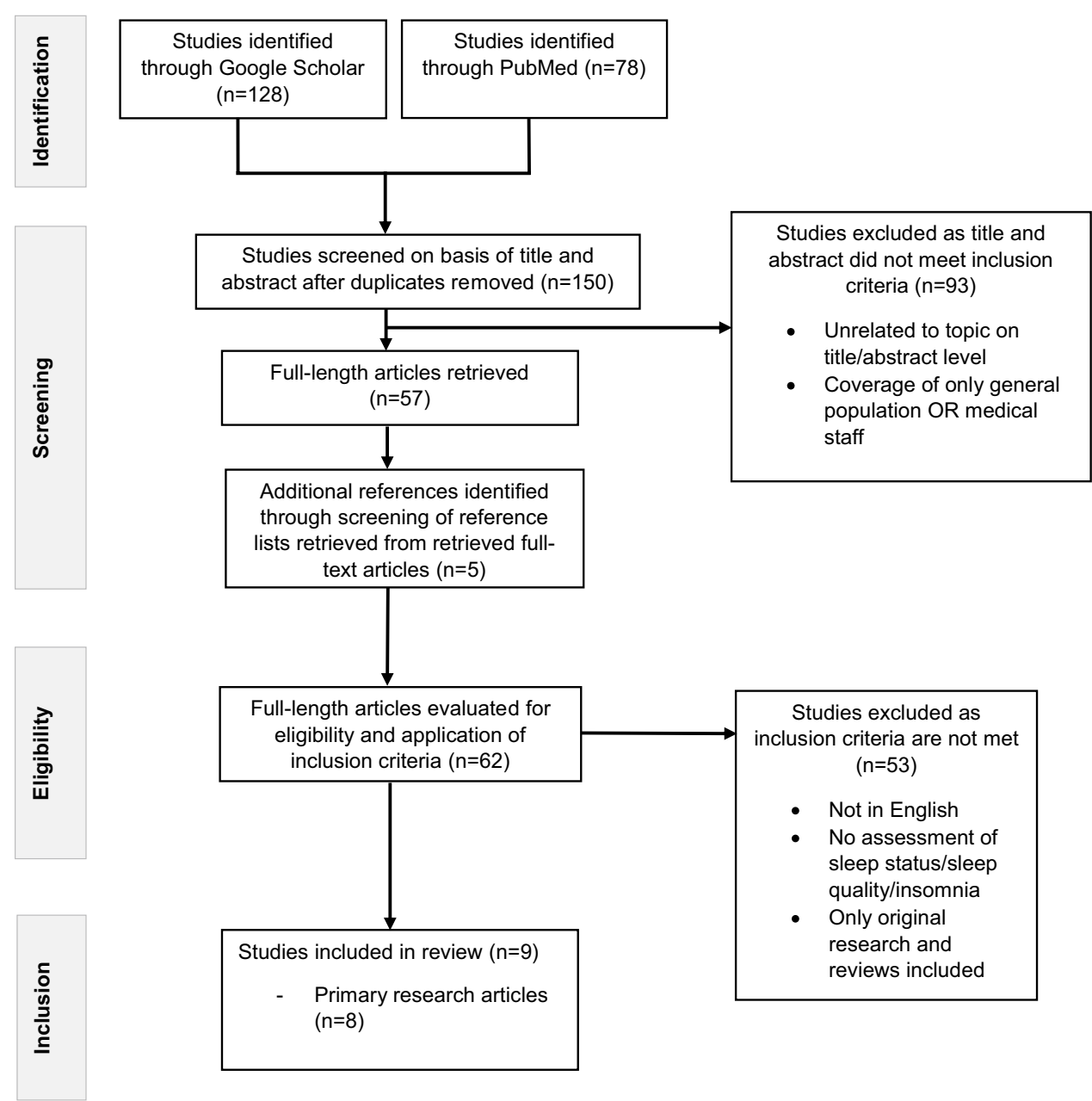


Fig. 2 Flowchart according to the PRISMA criteria on sleep disorders in healthcare providers under the COVID-19 pandemic condition

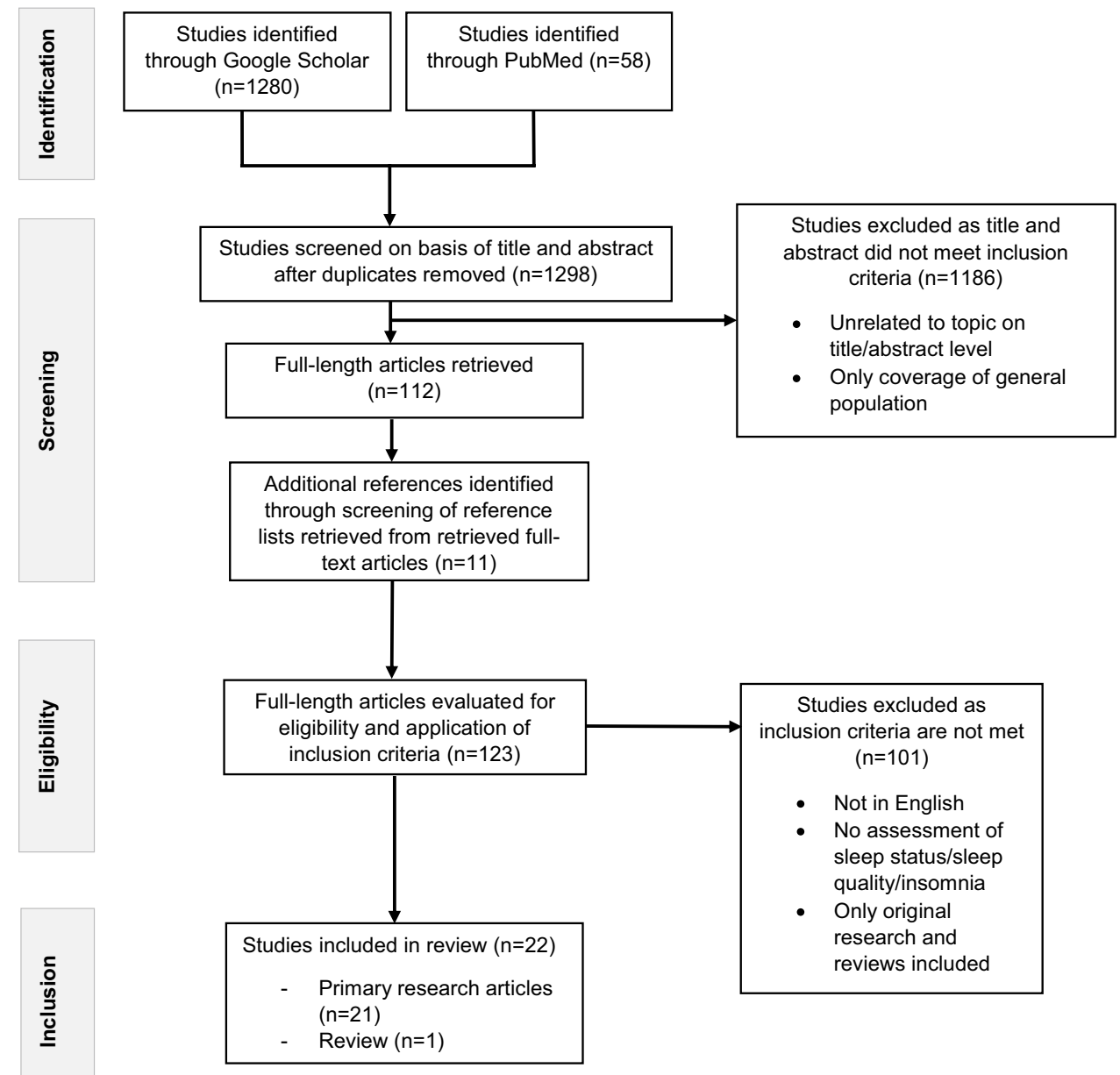

Poor sleep quality was consequently associated with the lower levels of lymphocytes in the blood of COVID-19 patients [58]. To this end, deep sleep modulates the T-Help cell response that plays a key role in the immune response towards viral infections suggesting that a focus on improving sleep quality in COVID-19 patients may be decisive for the recovery.

Further, an evident gender difference has been observed: female patients suffered more frequently from poorer psychiatric outcomes, such as depression and anxiety, compared to the male patients $[52,53]$.

To improve sleep quality in COVID-19 patients, Liu et al. suggest implementing progressive muscle relaxation, for which anxiety-relieving effects were also reported [54].

\section{Sleep quality in the healthcare givers under the COVID-19 pandemic condition}

Table 2 presents the collected data with corresponding interpretation towards analysed sleep quality in healthcare givers. The analysed data indicate that working with
COVID-19-affected patients is associated not only with a poorer sleep quality and insomnia symptoms, but also with mental health risks such as increased stress and burnout as well as a strong predisposition to mental disorders such as depression and anxiety [56, 57, 59-77].

In agreement with earlier demonstrated sex differences in the sleep quality $[81,82]$, female sex is associated with poorer sleep outcomes. The collected data indicate that female healthcare givers working in shifts during the pandemic are at significantly higher risk for insomnia and other mental health disturbances. In consensus with previous studies dedicated to the sleep quality for the shift workers, female nurses are at increased risk to develop sleep disorders and to a cancer predisposition. In summary, working in shifts with the COVID19-affected patients significantly increases overall risk of adverse effects to nurses' health. 


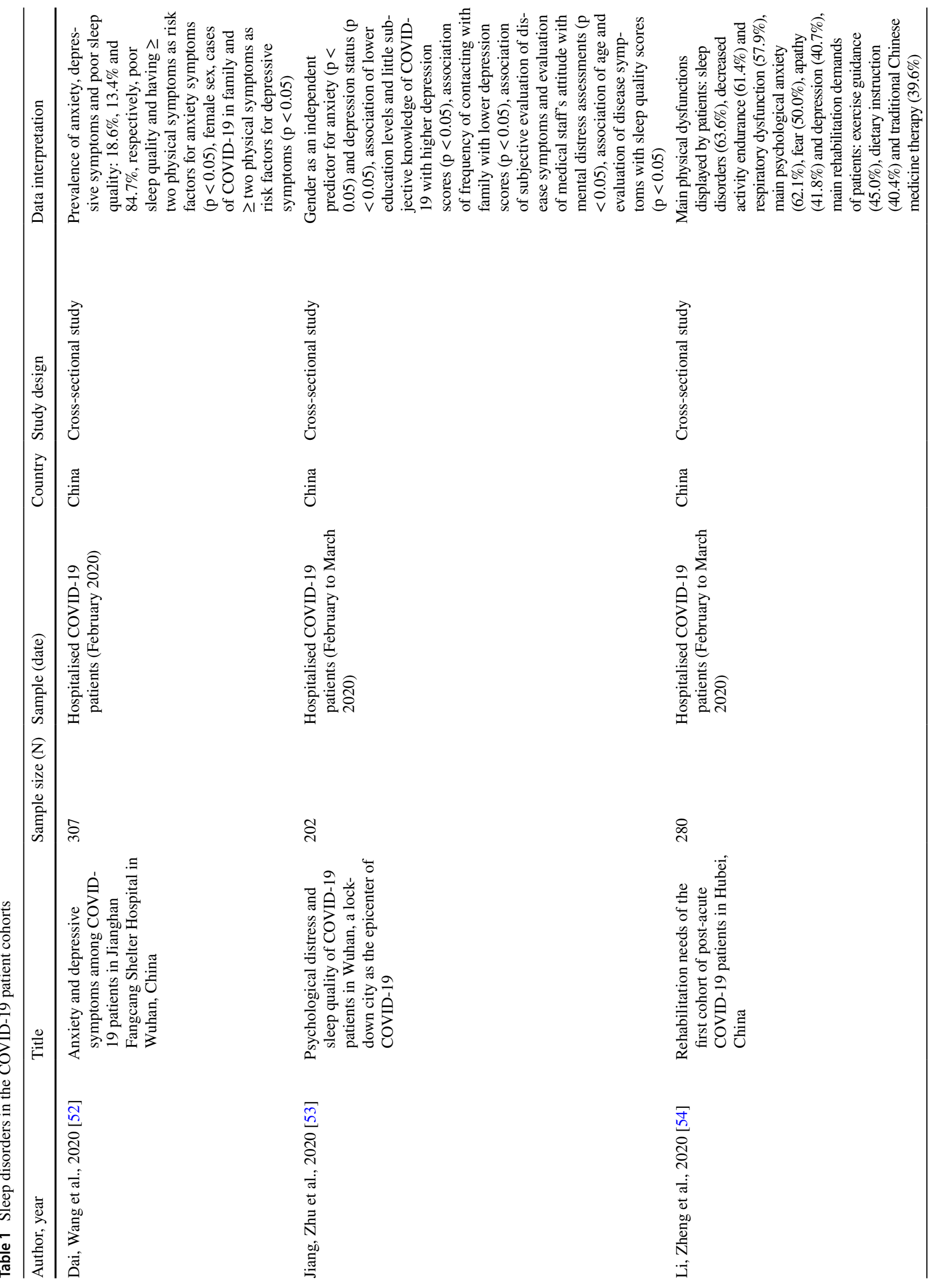




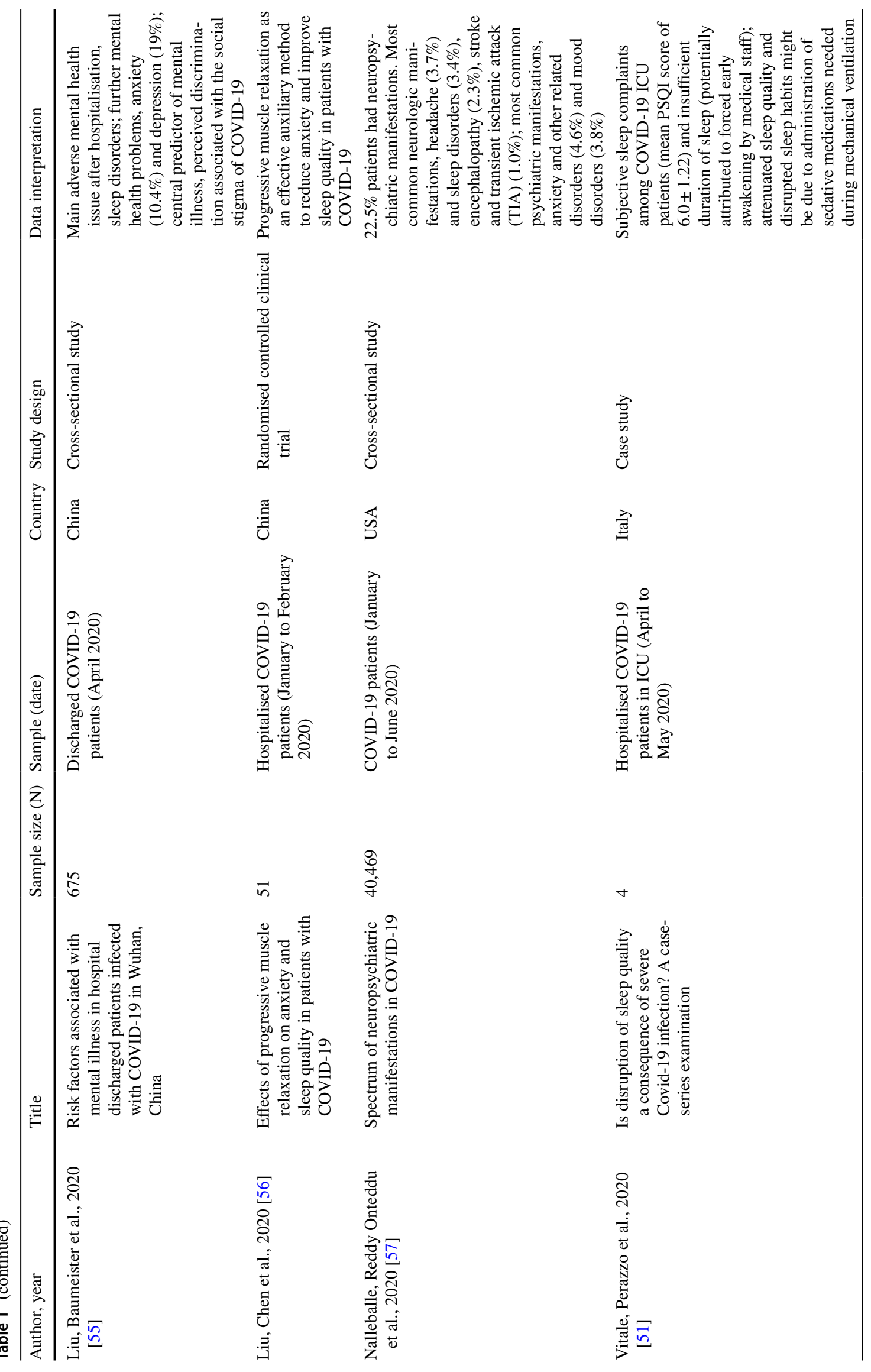




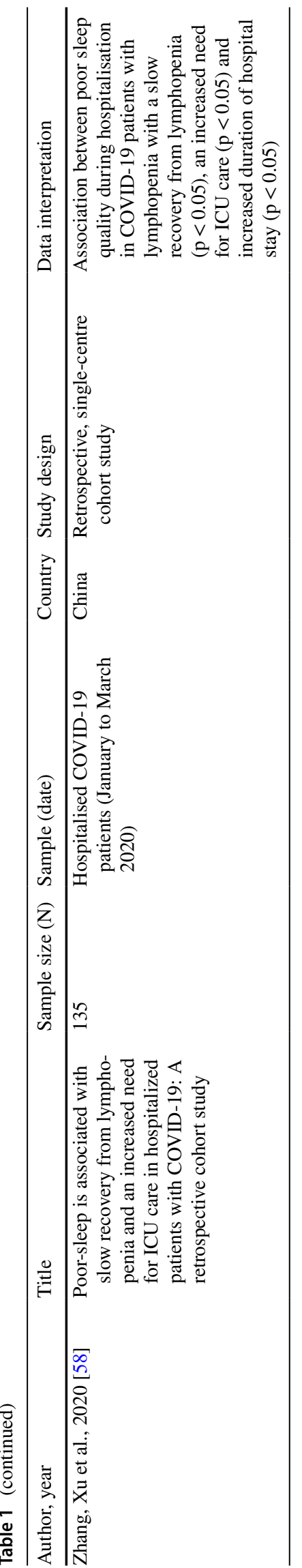

Conclusions and expert recommendations in the framework of $3 \mathrm{P}$ medicine

\section{Being frontline healthcare givers under COVID-19 pandemics}

Data collected clearly demonstrate that particularly frontline healthcare givers reported worse sleep outcome variables, such as insomnia symptoms or significantly decreased sleep quality accompanied by increased levels of stress and burnout as well as increased appearance of psychiatric symptoms such as depression and anxiety. Indeed, under the pandemic condition, the frontline healthcare givers are facing sudden outbreak, which given the severity of the pandemic leads to the work overloads and extended working time frame with insufficient time to recover and consequent chronic exposure to stress, psychological distress [47] and increased vulnerability to the stress-related disorders including viral infections.

Sleep deprivation in shift workers is associated with a higher incidence and severity of respiratory infections compared to non-shift workers [43, 44], suggesting that shift workers are more susceptible to COVID-19 infection and, consequently, to severe disease outcomes. In consensus, being dependent on the individual circadian rhythms, the adaptive and innate immune systems are disrupted by working in shifts. This in turn increases susceptibility of the affected individuals to infections [10, 38-40, 83]. To this end, the analysed molecular mechanisms argue in favour of a severe impairment of the immune memory in shift workers.

However, stress response and stress-related predisposition to pathologies have been demonstrated as being highly individual. Contextually, for working in shifts, an application of predictive diagnostic and patient stratification approaches followed by the targeted preventive measures is strongly recommended utilising corresponding tools and recommendations developed for a population screening and identification of individuals in sub-optimal health conditions $[84,85]$ and insomnia [86].

Contextually, perceived social and psychological support is considered as the preventive strategy to mild poor sleep quality and psychiatric symptoms in healthcare givers treating the COVID-19-affected patients [74, 75, 77, 78]. Recent studies on insomnia and sleep disorders related to working in shifts further indicate good effects for Internet-based interventions and conclude that hospital authorities are well advised to offer this new approach to their staff as part of workplace health promotion [87].

\section{Being COVID-19-affected}

Analysed data clearly demonstrate that insomnia symptoms persist in big portion of the COVID-19 patient cohort with 


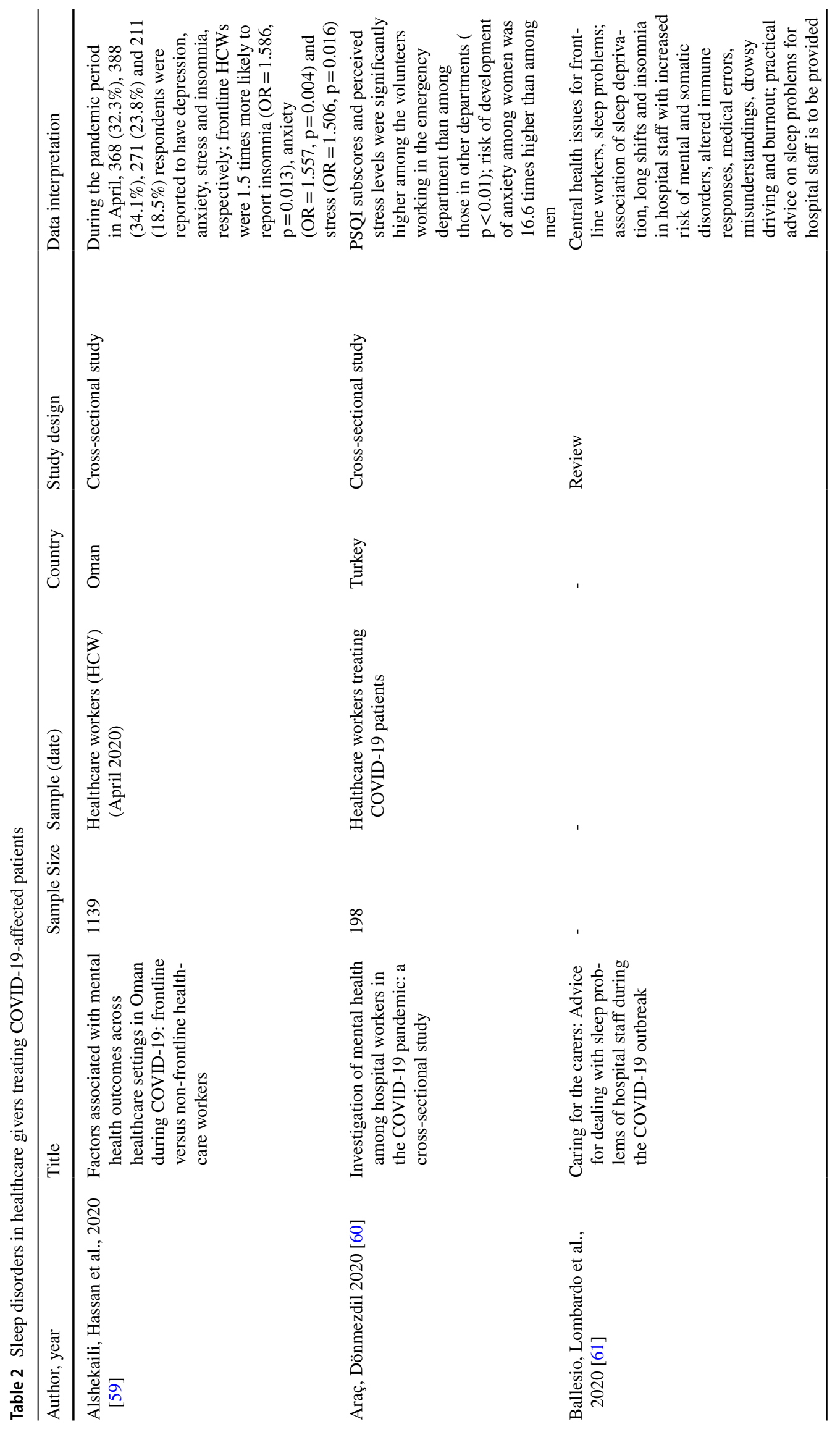




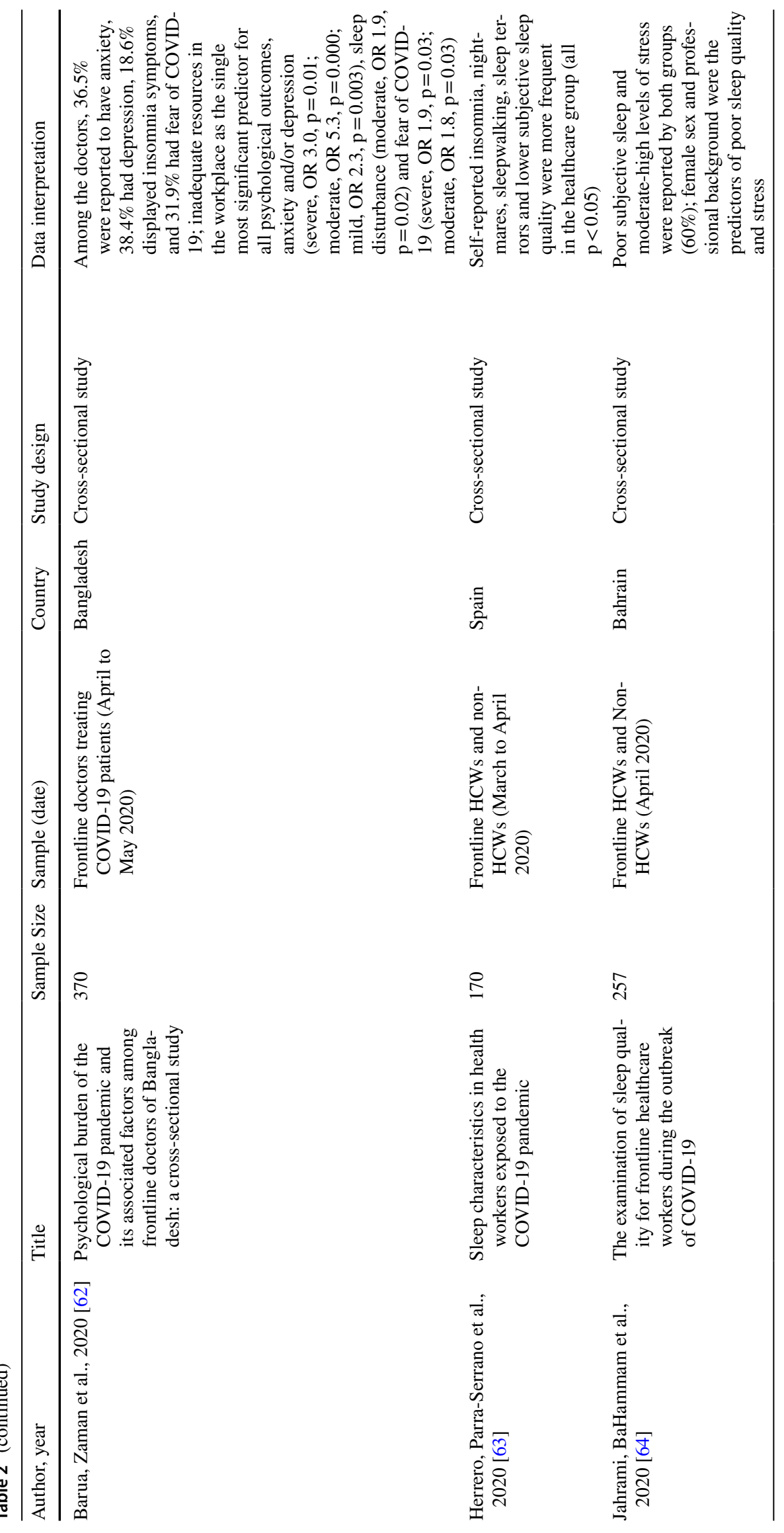




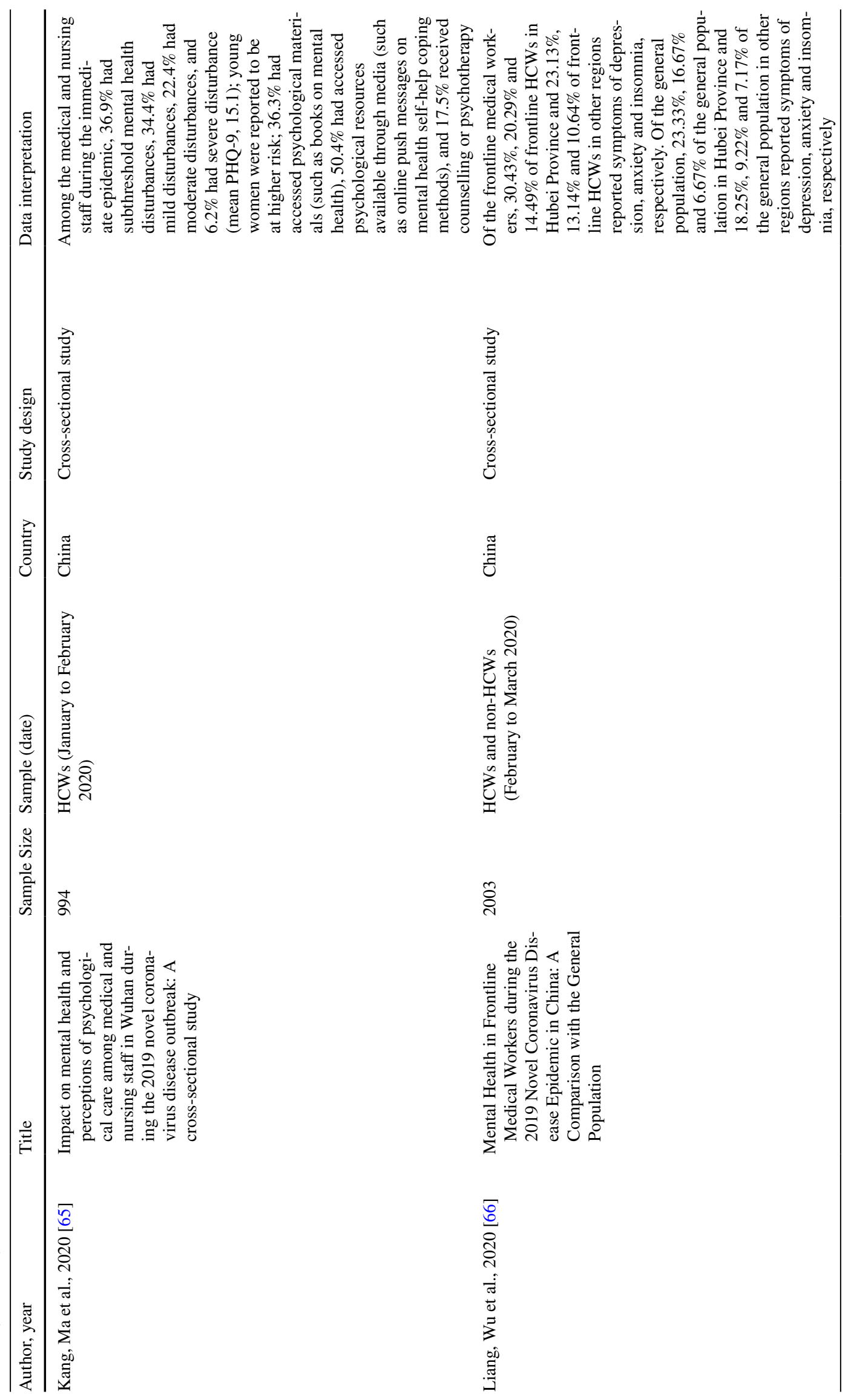




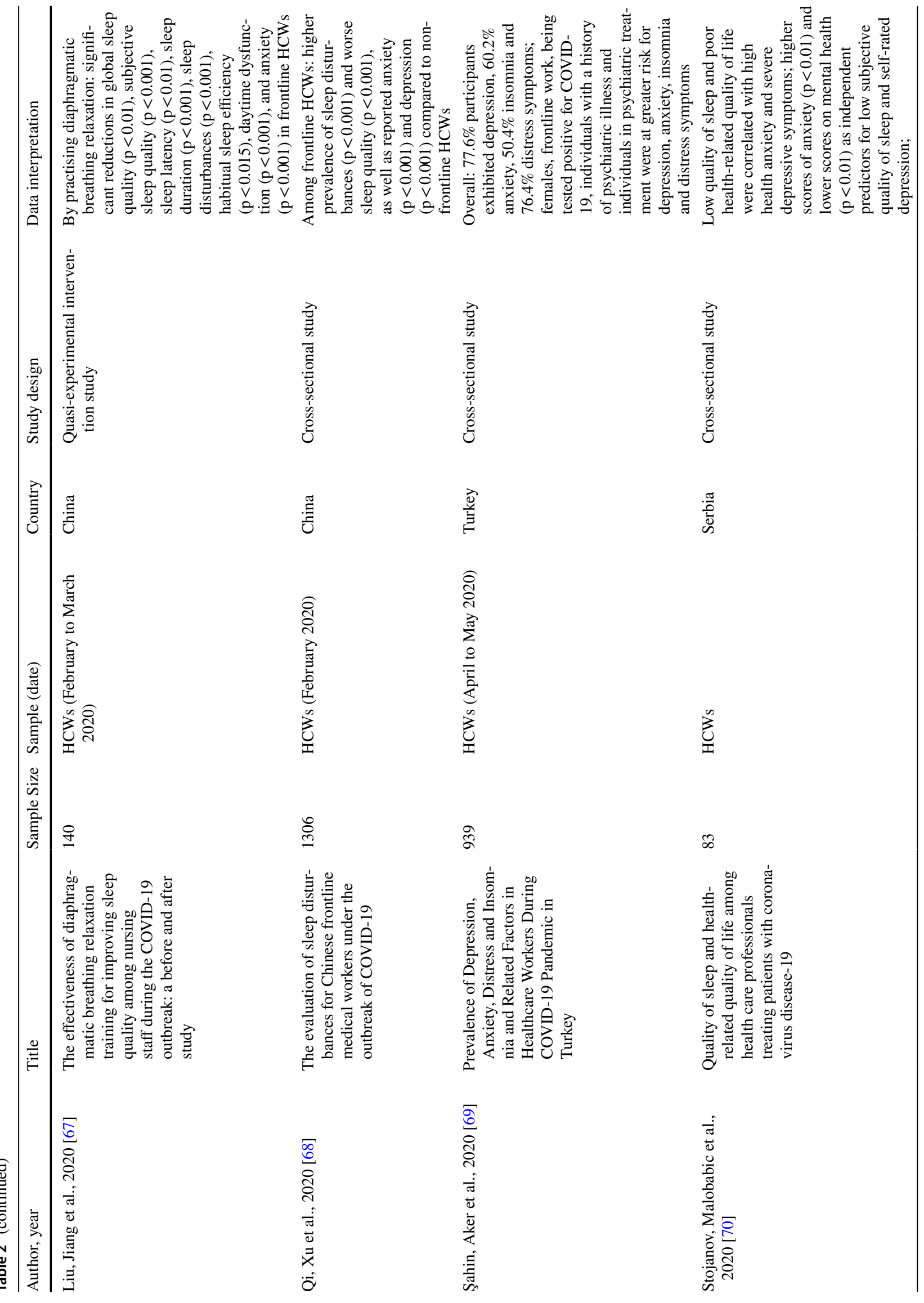




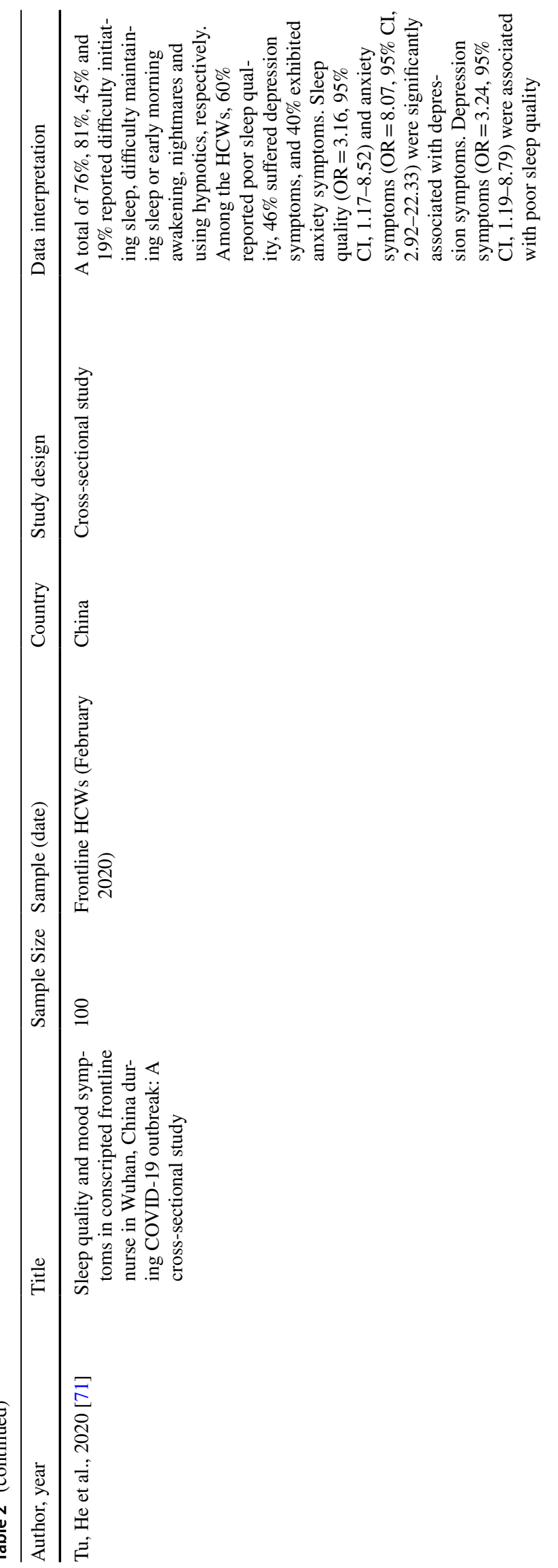




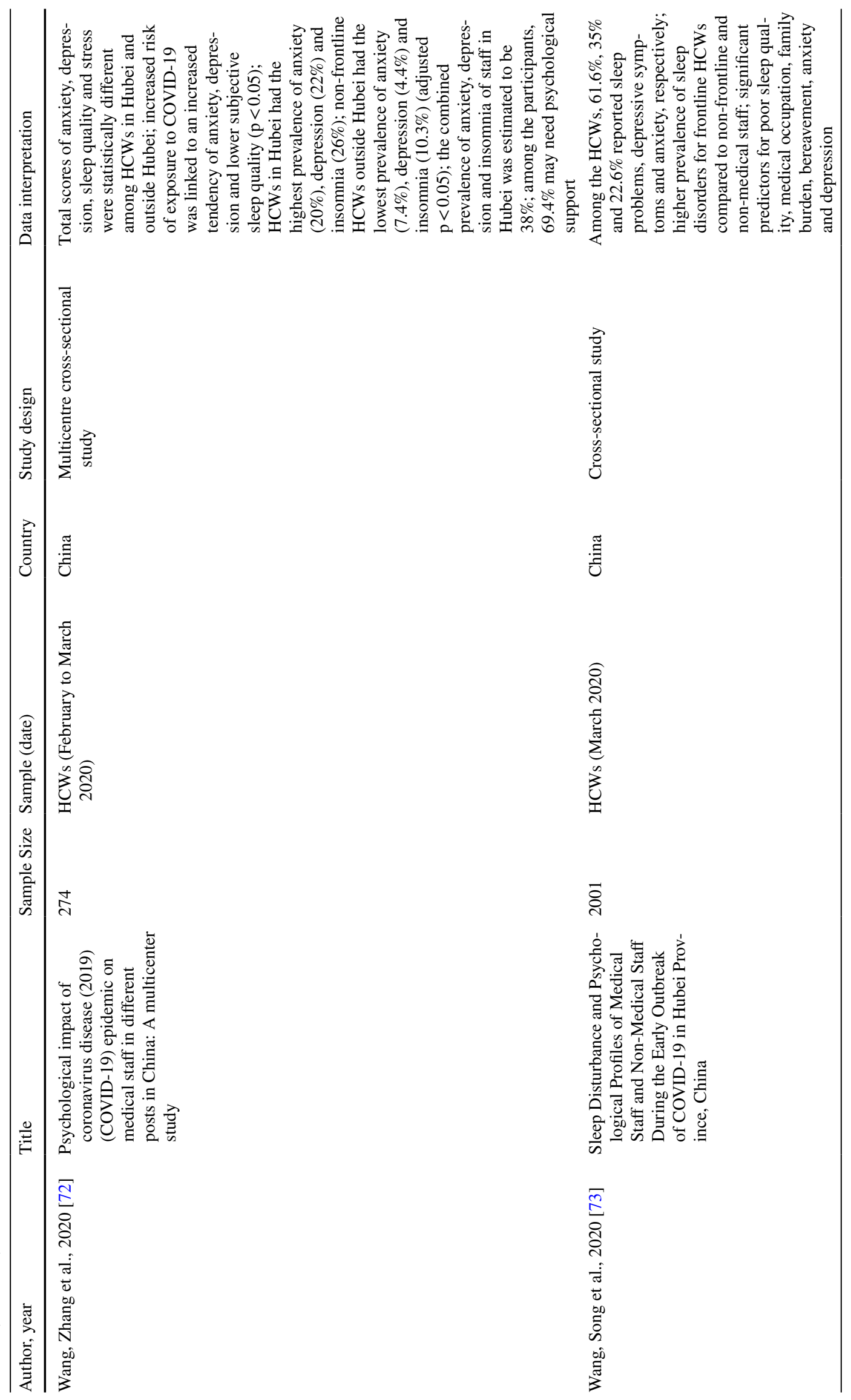




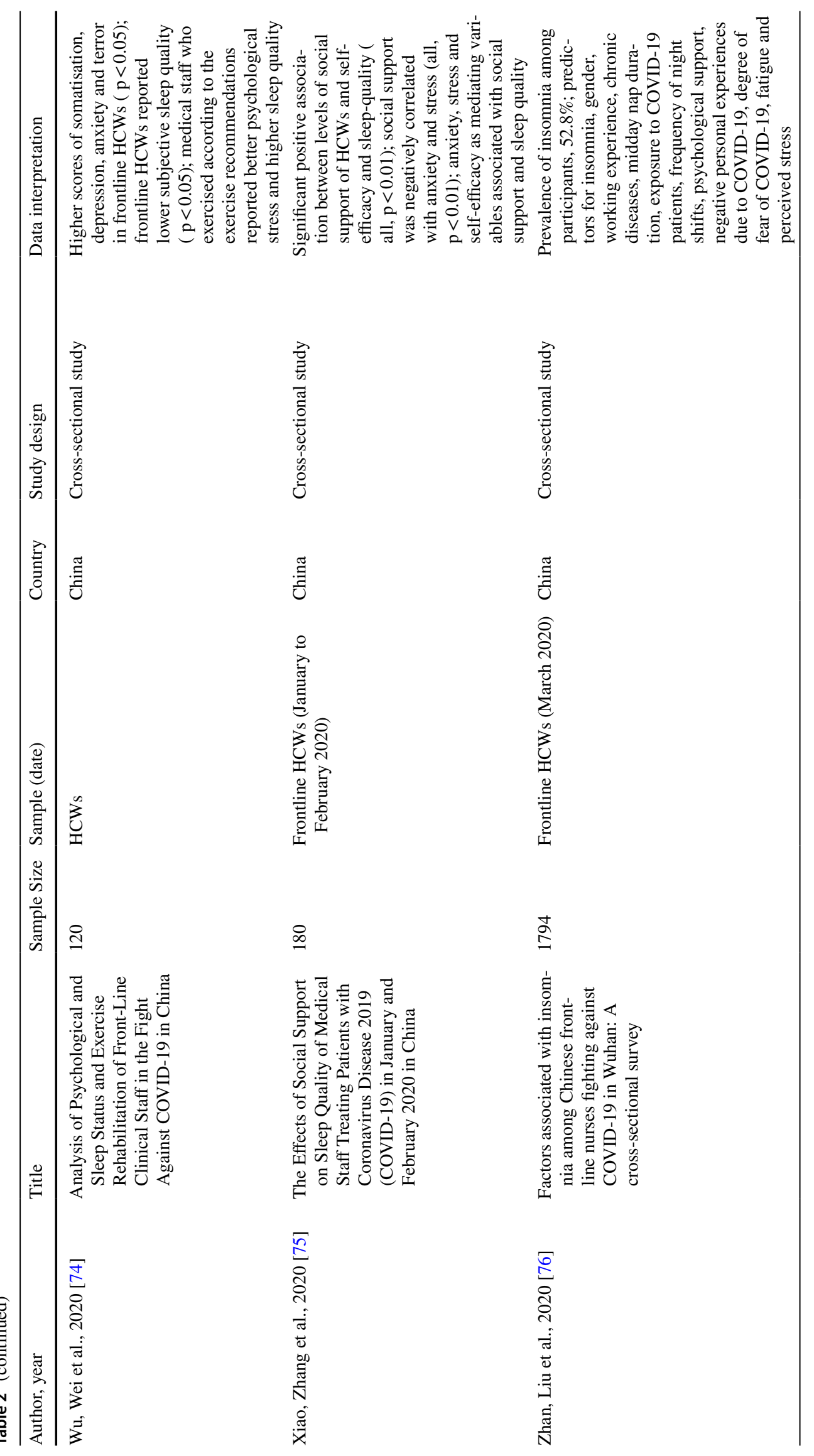




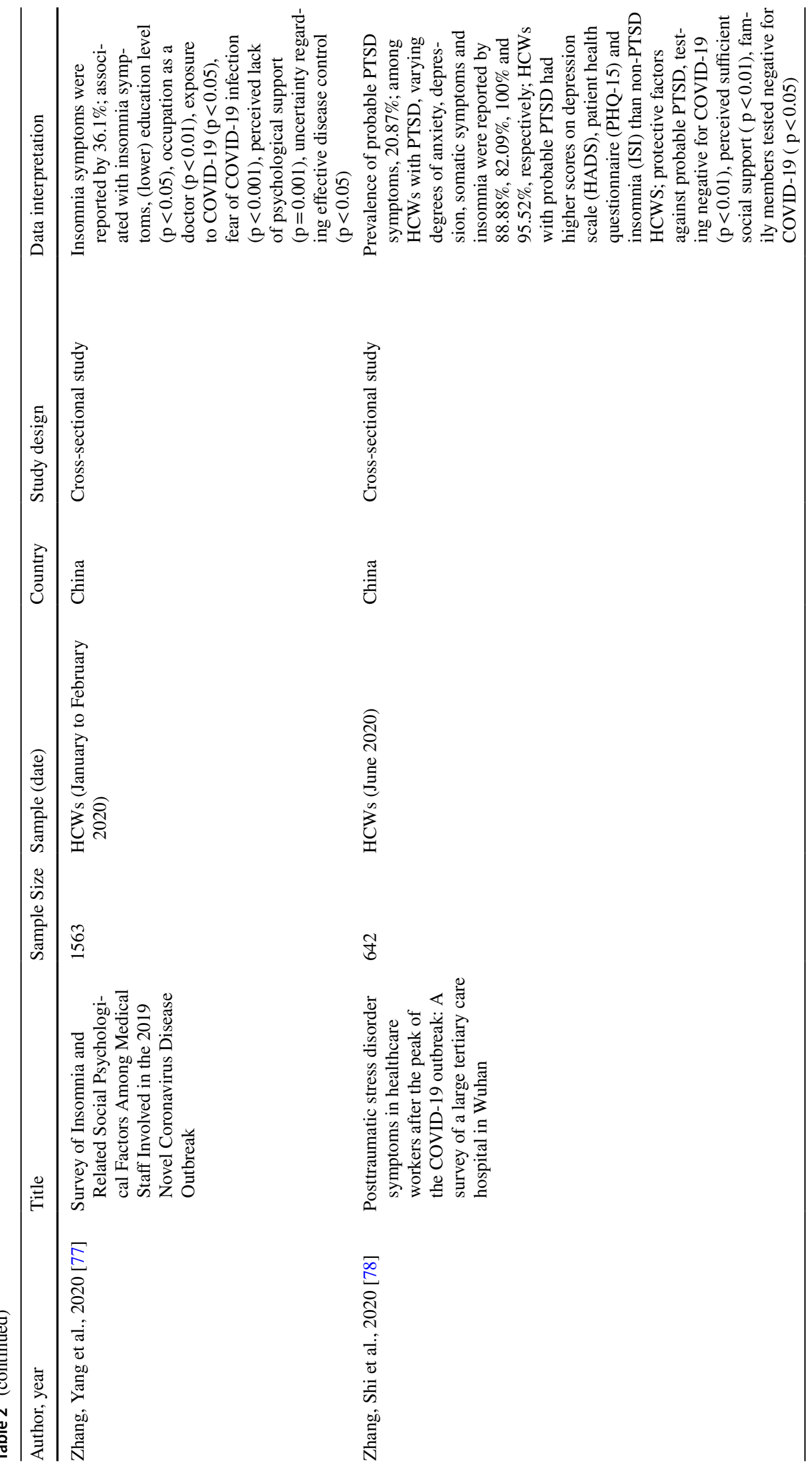




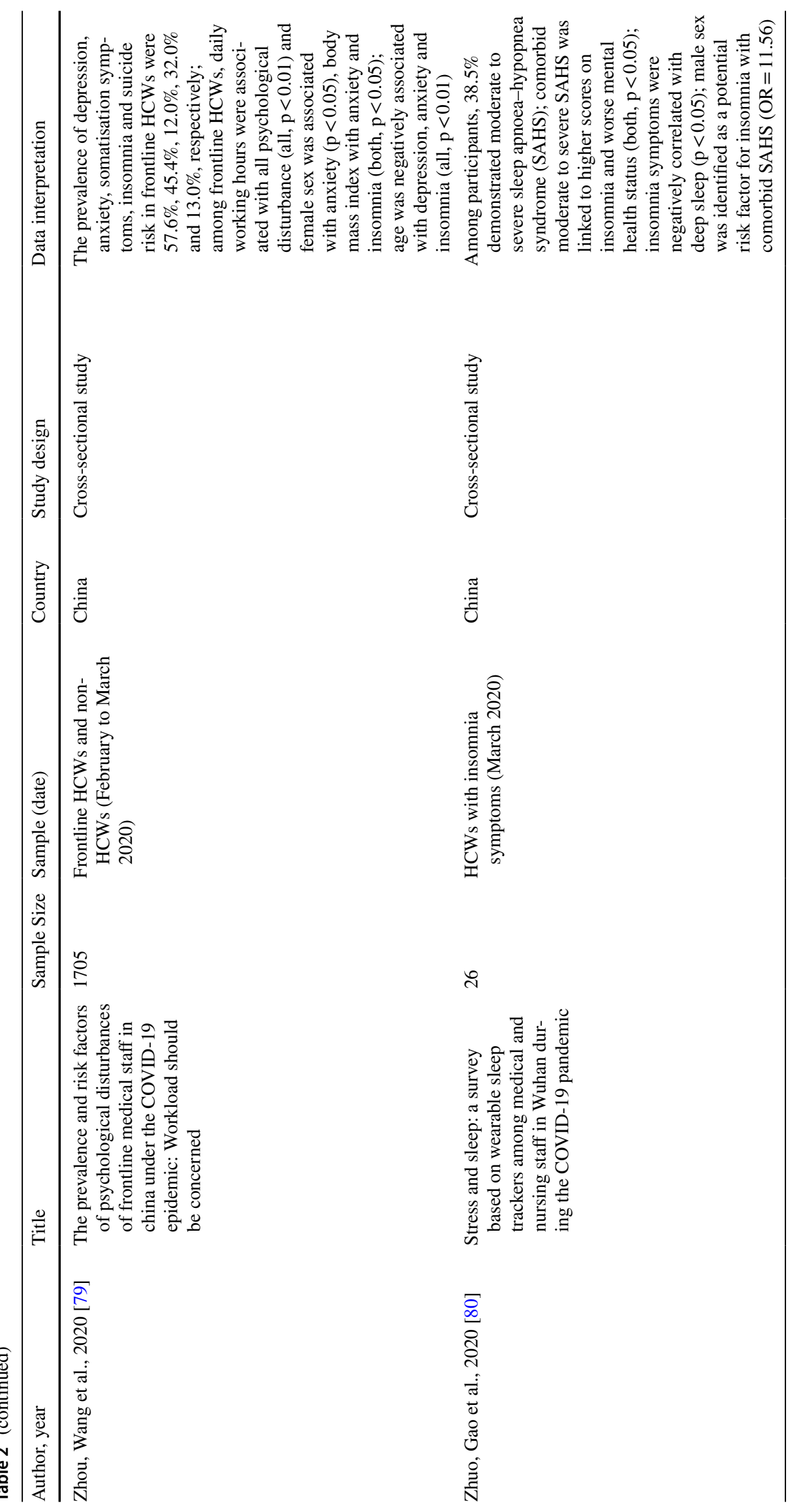


the monitored prevalence which significantly exceeds the level of insomnia in the general population. Several underlying causes have been proposed. Poor sleep quality was further associated with the decreased immune system functionality in the COVID-19 patients [58], suggesting that a focus on improving sleep quality may be decisive for the recovery and significantly better individual outcomes of the disease. Further, an evident gender difference indicates that particularly for the female patients, the focus on psychiatric aspects such as frequent depression and anxiety is strongly recommended as an essential part of individualised antiCOVID-19 treatment algorithms.

\section{Generalised anti-COVID-19 prevention}

As the generalised anti-COVID-19 prevention, the evidencebased periodontal healthcare is strongly recommended [5].

To this end, periodontopathic microflora is implicated in systemic inflammation and pneumonia development, in severe cases leading to sepsis and death. Diagnosed periodontitis is associated with high risk of admission to intensive care units and increased COVID-19-related death [88]. To this end, educational measures play a pivotal role, conducting principles of participatory medicine as an essential element of 3PM and promoting an active participation of patients in the treatment procedure and taking great responsibility for their health status [5].

Taking into account multi-faceted anti-inflammatory and anti-mitochondriopathic effects of melatonin, melatonin treatment is strongly recommended as an essential pillar of the anti-COVID-19 protection for the shift workers, COVID19-affected individuals and patients suffering from chronic non-communicable disorders under the viral pandemic conditions [89-91].

Author contributions KR and OG have created concepts of the study. KR has coordinated the project and drafted the paper. SK has performed literature search and drafted the data interpretation. OG has elaborated on the 3PM aspects. OG, KR and TH have elaborated on the final version of the manuscript. All authors have read and approved the final version.

Funding Open Access funding enabled and organized by Projekt DEAL.

Data availability Not applicable.

Code availability Not applicable.

\section{Declarations}

Ethics approval Not applicable.
Consent to participate Not applicable.

Consent for publication Not applicable.

Conflict of interest The authors declare no competing interests.

Open Access This article is licensed under a Creative Commons Attribution 4.0 International License, which permits use, sharing, adaptation, distribution and reproduction in any medium or format, as long as you give appropriate credit to the original author(s) and the source, provide a link to the Creative Commons licence, and indicate if changes were made. The images or other third party material in this article are included in the article's Creative Commons licence, unless indicated otherwise in a credit line to the material. If material is not included in the article's Creative Commons licence and your intended use is not permitted by statutory regulation or exceeds the permitted use, you will need to obtain permission directly from the copyright holder. To view a copy of this licence, visit http://creativecommons.org/licenses/by/4.0/.

\section{References}

1. Radanliev P, De Roure D, Walton R, Van Kleek M, Montalvo RM, Santos O, Maddox L, Cannady S. COVID-19 what have we learned? The rise of social machines and connected devices in pandemic management following the concepts of predictive, preventive and personalized medicine. EPMA J. 2020;11(3):311-32. https://doi.org/10.1007/s13167-020-00218-x.

2. Chaari L, Golubnitschaja O. Covid-19 pandemic by the "realtime" monitoring: the Tunisian case and lessons for global epidemics in the context of 3PM strategies. EPMA J. 2020;11(2):1-6. https://doi.org/10.1007/s13167-020-00207-0.

3. Zhao X, Wang K, Zuo P, Liu Y, Zhang M, Xie S, Zhang H, Chen $\mathrm{X}$, Liu C. Early decrease in blood platelet count is associated with poor prognosis in COVID-19 patients-indications for predictive, preventive, and personalized medical approach. EPMA J. 2020;11(2):1-7. https://doi.org/10.1007/s13167-020-00208-z.

4. Ahluwalia P, Ahluwalia M, Vaibhav K, Mondal A, Sahajpal N, Islam S, Fulzele S, Kota V, Dhandapani K, Baban B, Rojiani AM, Kolhe R. Infections of the lung: a predictive, preventive and personalized perspective through the lens of evolution, the emergence of SARS-CoV-2 and its pathogenesis. EPMA J. 2020;11(4):1-21. https://doi.org/10.1007/s13167-020-00230-1.

5. Tachalov VV, Orekhova LY, Kudryavtseva TV, Loboda ES, Pachkoriia MG, Berezkina IV, Golubnitschaja O. Making a complex dental care tailored to the person: population health in focus of predictive, preventive and personalised (3P) medical approach. EPMA J. 2021. https://doi.org/10.1007/s13167-021-00240-7.

6. Lange T, Dimitrov S, Born J. Effects of sleep and circadian rhythm on the human immune system. Ann N Y Acad Sci. 2010;1193:4859. https://doi.org/10.1111/j.1749-6632.2009.05300.x.

7. Besedovsky L, Lange T, Born J. Sleep and immune function. Pflugers Arch. 2012;463(1):121-37. https://doi.org/10.1007/ s00424-011-1044-0.

8. Dinges DF, Douglas SD, Zaugg L, Campbell DE, McMann JM, Whitehouse WG, Orne EC, Kapoor SC, Icaza E, Orne MT. Leukocytosis and natural killer cell function parallel neurobehavioral fatigue induced by 64 hours of sleep deprivation. J Clin Invest. 1994;93(5):1930-9. https://doi.org/10.1172/JCI117184.

9. Dinges DF, Douglas SD, Hamarman S, Zaugg L, Kapoor S. Sleep deprivation and human immune function. Adv Neuroimmunol. 1995;5(2):97-110. https://doi.org/10.1016/0960-5428(95)00002-j.

10. Silva FRD, Guerreiro RC, Andrade HA, Stieler E, Silva A, de Mello MT. Does the compromised sleep and circadian 
disruption of night and shiftworkers make them highly vulnerable to 2019 coronavirus disease (COVID-19)? Chronobiol Int. 2020;37(5):607-17. https://doi.org/10.1080/07420528.2020. 1756841

11. Biron CA, Nguyen KB, Pien GC, Cousens LP, Salazar-Mather TP. Natural killer cells in antiviral defense: function and regulation by innate cytokines. Annu Rev Immunol. 1999;17:189-220. https:// doi.org/10.1146/annurev.immunol.17.1.189.

12. Prather AA, Marsland AL, Hall M, Neumann SA, Muldoon MF, Manuck SB. Normative variation in self-reported sleep quality and sleep debt is associated with stimulated pro-inflammatory cytokine production. Biol Psychol. 2009;82(1):12-7. https://doi. org/10.1016/j.biopsycho.2009.04.008.

13. Wilder-Smith A, Mustafa FB, Earnest A, Gen L, Macary PA. Impact of partial sleep deprivation on immune markers. Sleep Med. 2013;14(10):1031-4. https://doi.org/10.1016/j.sleep.2013. 07.001 .

14. Levy SM, Heiden L. Depression, distress, and immunity: risk factors for infectious disease. Stress Med. 1991;7(1):45-51. https:// doi.org/10.1002/smi.2460070109.

15. Irwin M, Mascovich A, Gillin JC, Willoughby R, Pike J, Smith TL. Partial sleep deprivation reduces natural killer cell activity in humans. Psychosom Med. 1994;56(6):493-8. https://doi.org/10. 1097/00006842-199411000-00004.

16. Irwin M, McClintick J, Costlow C, Fortner M, White J, Gillin JC. Partial night sleep deprivation reduces natural killer and cellular immune responses in humans. FASEB J. 1996;10(5):643-53. https://doi.org/10.1096/fasebj.10.5.8621064.

17. Huang $\mathrm{C}$, et al. 6-month consequences of COVID-19 in patients discharged from hospital: a cohort study. Lancet. 2021;397(10270):220-32. https://doi.org/10.1016/s01406736(20)32656-8

18. Yang X, Yu Y, Xu J, Shu H, Xia J, Liu H, Wu Y, Zhang L, Yu Z, Fang M, Yu T, Wang Y, Pan S, Zou X, Yuan S, Shang Y. Clinical course and outcomes of critically ill patients with SARSCoV-2 pneumonia in Wuhan, China: a single-centered, retrospective, observational study. Lancet Respir Med. 2020;8(5):475-81. https://doi.org/10.1016/S2213-2600(20)30079-5.

19. Bloomgarden ZT. Diabetes and COVID-19. J Diabetes. 2020;12(4):347-8. https://doi.org/10.1111/1753-0407.13027.

20. Guo YR, Cao QD, Hong ZS, Tan YY, Chen SD, Jin HJ, Tan KS, Wang DY, Yan Y. The origin, transmission and clinical therapies on coronavirus disease 2019 (COVID-19) outbreak - an update on the status. Mil Med Res. 2020;7(1):11. https://doi.org/10.1186/ s40779-020-00240-0.

21. Benedict C, Cedernaes J. Could a good night's sleep improve COVID-19 vaccine efficacy? Lancet Respir Med. 2021;12:S22132600(21)00126-0. https://doi.org/10.1016/S2213-2600(21) 00126-0.

22. Reiter PL, McRee AL, Kadis JA, Brewer NT. HPV vaccine and adolescent males. Vaccine. 2011;29(34):5595-602. https://doi. org/10.1016/j.vaccine.2011.06.020.

23. Lange T, Dimitrov S, Bollinger T, Diekelmann S, Born J. Sleep after vaccination boosts immunological memory. J Immunol. 2011;187(1):283-90. https://doi.org/10.4049/jimmunol.1100015.

24. Beigel JH, Tomashek KM, Dodd LE. Remdesivir for the treatment of Covid-19 - preliminary report. Reply N Engl J Med. 2020;383(10):994. https://doi.org/10.1056/NEJMc2022236.

25. Beigel JH, Tomashek KM, Dodd LE, Mehta AK, Zingman BS, Kalil AC, Hohmann E, Chu HY, Luetkemeyer A, Kline S, Lopez de Castilla D, Finberg RW, Dierberg K, Tapson V, Hsieh L, Patterson TF, Paredes R, Sweeney DA, Short WR, Touloumi G, Lye DC, Ohmagari N, Oh MD, Ruiz-Palacios GM, Benfield T, Fätkenheuer G, Kortepeter MG, Atmar RL, Creech CB, Lundgren J, Babiker AG, Pett S, Neaton JD, Burgess TH, Bonnett T, Green
M, Makowski M, Osinusi A, Nayak S, Lane HC, ACTT-1 Study Group Members. Remdesivir for the treatment of Covid-19 - final report. N Engl J Med. 2020;383(19):181-1826. https://doi.org/10. 1056/NEJMoa2007764.

26. Zhou Y, Hou Y, Shen J, Kallianpur A, Zein J, Culver DA, Farha S, Comhair S, Fiocchi C, Gack MU, Mehra R, Stappenbeck T, Chan T, Eng C, Jung JU, Jehi L, Erzurum S, Cheng F. A network medicine approach to investigation and population-based validation of disease manifestations and drug repurposing for COVID-19. ChemRxiv [Preprint]. 2020. https://doi.org/10.26434/chemrxiv. 12579137. Update in: PLoS Biol. 2020;18(11):e3000970.

27. Ramlall V, Zucker J, Tatonetti N. Melatonin is significantly associated with survival of intubated COVID-19 patients. medRxiv [Preprint]. 2020. https://doi.org/10.1101/2020.10.15.20213546.

28. Chen C, Zhang XR, Ju ZY, He WF. [Advances in the research of mechanism and related immunotherapy on the cytokine storm induced by coronavirus disease 2019]. Zhonghua Shao Shang Za Zhi. 2020;36(6):471-5. https://doi.org/10.3760/cma.j.cn50112020200224-00088. Chinese.

29. El-Missiry MA, El-Missiry ZMA, Othman AI. Melatonin is a potential adjuvant to improve clinical outcomes in individuals with obesity and diabetes with coexistence of Covid-19. Eur J Pharmacol. 2020;882:173329. https://doi.org/10.1016/j.ejphar. 2020.173329.

30. Reiter RJ, Abreu-Gonzalez P, Marik PE, Dominguez-Rodriguez A. Therapeutic algorithm for use of melatonin in patients with COVID-19. Front Med (Lausanne). 2020;7:226. https://doi.org/ 10.3389/fmed.2020.00226.

31. Zhang R, Wang X, Ni L, Di X, Ma B, Niu S, Liu C, Reiter RJ. COVID-19: Melatonin as a potential adjuvant treatment. Life Sci. 2020;250:117583. https://doi.org/10.1016/j.lfs.2020.117583.

32. Kobayashi F, Hikari F, Yasuhiro A, Takemasa W, Hiroshi H. Changes in psychophysiological functions during night shift in nurses. Int Arch Occup Environ Health. 1996;69(2):83-90. https:// doi.org/10.1007/s004200050120.

33. Xu X, Ding M, Li B, Christiani DC. Association of rotating shiftwork with preterm births and low birth weight among never smoking women textile workers in China. Occup Environ Med. 1994;51(7):470-4. https://doi.org/10.1136/oem.51.7.470.

34. Akerstedt T, Gillberg M. Subjective and objective sleepiness in the active individual. Int J Neurosci. 1990;52(1-2):29-37. https:// doi.org/10.3109/00207459008994241.

35. Schernhammer ES, Laden F, Speizer FE, Willett WC, Hunter DJ, Kawachi I, Colditz GA. Rotating night shifts and risk of breast cancer in women participating in the nurses' health study. J Natl Cancer Inst. 2001;93(20):1563-8. https://doi.org/10.1093/jnci/93. 20.1563

36. Knutsson A. Health disorders of shift workers. Occup Med. 2003;53(2):103-8. https://doi.org/10.1093/occmed/kqg048.

37. Reinberg A, Ashkenazi I. Internal desynchronization of circadian rhythms and tolerance to shift work. Chronobiol Int. 2008;25(4):625-43. https://doi.org/10.1080/07420520802256101.

38. Loef B, van Baarle D, van der Beek AJ, van Kerkhof LW, van de Langenberg D, Proper KI. Klokwerk + study protocol: an observational study to the effects of night-shift work on body weight and infection susceptibility and the mechanisms underlying these health effects. BMC Public Health. 2016;16:692. https://doi.org/ 10.1186/s12889-016-3317-1.

39. Ananthakrishnan AN, Cagan A, Cai T, Gainer VS, Shaw SY, Churchill S, Karlson EW, Murphy SN, Kohane I, Liao KP. Diabetes and the risk of infections with immunomodulator therapy in inflammatory bowel diseases. Aliment Pharmacol Ther. 2015;41(11):1141-8. https://doi.org/10.1111/apt.13195.

40. Anderson JR, Carroll I, Azcarate-Peril MA, Rochette AD, Heinberg LJ, Peat C, Steffen K, Manderino LM, Mitchell J, Gunstad 
J. A preliminary examination of gut microbiota, sleep, and cognitive flexibility in healthy older adults. Sleep Med. 2017;38:104-7. https://doi.org/10.1016/j.sleep.2017.07.018.

41. Cohen S, Doyle WJ, Alper CM, Janicki-Deverts D, Turner RB. Sleep habits and susceptibility to the common cold. Arch Intern Med. 2009;169(1):62-7. https://doi.org/10.1001/archinternmed. 2008.505.

42. Patel SR, Malhotra A, Gao X, Hu FB, Neuman MI, Fawzi WW. A prospective study of sleep duration and pneumonia risk in women. Sleep. 2012;35(1):97-101. https://doi.org/10.5665/sleep.1594.

43. Archer SN, Oster H. How sleep and wakefulness influence circadian rhythmicity: effects of insufficient and mistimed sleep on the animal and human transcriptome. J Sleep Res. 2015;24(5):47693. https://doi.org/10.1111/jsr.12307.

44. Archer SN, Schmidt C, Vandewalle G, Dijk DJ. Phenotyping of PER3 variants reveals widespread effects on circadian preference, sleep regulation, and health. Sleep Med Rev. 2018;40:109-26. https://doi.org/10.1016/j.smrv.2017.10.008.

45. Irwin M. Effects of sleep and sleep loss on immunity and cytokines. Brain Behav Immun. 2002;16(5):503-12. https://doi. org/10.1016/s0889-1591(02)00003-x.

46. Krueger JM, Clinton JM, Winters BD, Zielinski MR, Taishi P, Jewett KA, Davis CJ. Involvement of cytokines in slow wave sleep. Prog Brain Res. 2011;193:39-47. https://doi.org/10.1016/ B978-0-444-53839-0.00003-X.

47. Huang Y, Zhao N. Mental health burden for the public affected by the COVID-19 outbreak in China: who will be the high-risk group? Psychol Health Med. 2021;26(1):23-34. https://doi.org/ 10.1080/13548506.2020.1754438.

48. Richter K, Acker J, Adam S, Niklewski G. Prevention of fatigue and insomnia in shift workers-a review of non-pharmacological measures. EPMA J. 2016;7(1):16. https://doi.org/10.1186/ s13167-016-0064-4.

49. Bhaskar S, Hemavathy D, Prasad S. Prevalence of chronic insomnia in adult patients and its correlation with medical comorbidities. J Family Med Prim Care. 2016;5(4):780-4. https://doi.org/ 10.4103/2249-4863.201153.

50. Patel D, Steinberg J, Patel P. Insomnia in the elderly: a review. J Clin Sleep Med. 2018;14(6):1017-24. https://doi.org/10.5664/ jcsm.7172.

51. Vitale JA, Perazzo P, Silingardi M, Biffi M, Banfi G, Negrini F. Is Disruption of sleep quality a consequence of severe covid19 infection? A Case-series Examination. Chronobiol Int. 2020;37(7):1110-4. https://doi.org/10.1080/07420528.2020. 1775241.

52. Dai LL, Wang X, Jiang TC, Li PF, Wang Y, Wu SJ, Jia LQ, Liu M, An L, Cheng Z. Anxiety and depressive symptoms among COVID-19 patients in Jianghan Fangcang Shelter Hospital in Wuhan, China. PLoS One. 2020;15(8):e0238416. https://doi.org/ 10.1371/journal.pone.0238416.

53. Jiang Z, Zhu P, Wang L, Hu Y, Pang M, Ma S, Tang X. Psychological distress and sleep quality of COVID-19 patients in Wuhan, a lockdown city as the epicenter of COVID-19. J Psychiatr Res. 2021;136:595-602. https://doi.org/10.1016/j.jpsychires.2020.10. 034 .

54. Li Z, Zheng C, Duan C, Zhang Y, Li Q, Dou Z, Li J, Xia W. Rehabilitation needs of the first cohort of post-acute COVID-19 patients in Hubei, China. Eur J Phys Rehabil Med. 2020;56(3):339-44. https://doi.org/10.23736/S1973-9087.20.06298-X.

55. Liu D, Baumeister RF, Veilleux JC, Chen C, Liu W, Yue Y, Zhang S. Risk factors associated with mental illness in hospital discharged patients infected with COVID-19 in Wuhan, China. Psychiatry Res. 2020;292:113297. https://doi.org/10.1016/j.psych res.2020.113297.

56. Liu K, Chen Y, Wu D, Lin R, Wang Z, Pan L. Effects of progressive muscle relaxation on anxiety and sleep quality in patients with COVID-19. Complement Ther Clin Pract. 2020;39:101132. https://doi.org/10.1016/j.ctcp.2020.101132.

57. Nalleballe K, Reddy Onteddu S, Sharma R, Dandu V, Brown A, Jasti M, Yadala S, Veerapaneni K, Siddamreddy S, Avula A, Kapoor N, Mudassar K, Kovvuru S. Spectrum of neuropsychiatric manifestations in COVID-19. Brain Behav Immun. 2020;88:71-4. https://doi.org/10.1016/j.bbi.2020.06.020.

58. Zhang J, Xu D, Xie B, Zhang Y, Huang H, Liu H, Chen H, Sun Y, Shang Y, Hashimoto K, Yuan S. Poor-sleep is associated with slow recovery from lymphopenia and an increased need for ICU care in hospitalized patients with COVID-19: a retrospective cohort study. Brain Behav Immun. 2020;88:50-8. https://doi.org/ 10.1016/j.bbi.2020.05.075

59. Alshekaili M, Hassan W, Al Said N, et al. Factors associated with mental health outcomes across healthcare settings in Oman during COVID-19: frontline versus non-frontline healthcare workers. BMJ Open. 2020;10:e042030. https://doi.org/10.1136/bmjop en-2020-042030.

60. Araç S, Dönmezdil S. Investigation of mental health among hospital workers in the COVID-19 pandemic: a cross-sectional study. Sao Paulo Med J. 2020;138(5):433-40. https://doi.org/10.1590/ 1516-3180.2020.0272.R3.21072020.

61. Ballesio A, Lombardo C, Lucidi F, Violani C. Caring for the carers: advice for dealing with sleep problems of hospital staff during the COVID-19 outbreak. J Sleep Re. 2020;30(1). https://doi.org/ 10.1111/jsr.13096.

62. Barua L, Zaman MS, Omi FR, Faruque M. Psychological burden of the COVID-19 pandemic and its associated factors among frontline doctors of Bangladesh: a cross-sectional study. F1000Res. 2020;9:1304. https://doi.org/10.12688/f1000research. 27189.3.

63. Herrero San Martin A, Parra Serrano J, Diaz Cambriles T, Arias Arias EM, Muñoz Méndez J, Del Yerro Álvarez MJ, González Sánchez M. Sleep characteristics in health workers exposed to the COVID-19 pandemic. Sleep Med. 2020;75:388-94. https:// doi.org/10.1016/j.sleep.2020.08.013.

64. Jahrami H, Ahmed SB, Haifa A, Ahmed E, MoezAlIslam F, Kawthar A, Zahra S, Eman H, Ali D, Hussain M, Suad H, Zainab H. The examination of sleep quality for frontline healthcare workers during the outbreak of COVID-19. Sleep Breath. 2020;25(1):50311. https://doi.org/10.1007/s11325-020-02135-9.

65. Kang L, Ma S, Chen M, Yang J, Wang Y, Li R, Yao L, Bai H, Cai Z, Xiang Yang B, Hu S, Zhang K, Wang G, Ma C, Liu Z. Impact on mental health and perceptions of psychological care among medical and nursing staff in Wuhan during the 2019 novel coronavirus disease outbreak: a cross-sectional study. Brain Behav Immun. 2020;87:11-7. https://doi.org/10.1016/j.bbi.2020.03.028.

66. Liang Y, Wu K, Zhou Y, Huang X, Zhou Y, Liu Z. Mental health in frontline medical workers during the 2019 novel coronavirus disease epidemic in China: a comparison with the general population. Int J Environ Res Public Health. 2020;17(18):6550. https:// doi.org/10.3390/ijerph17186550.

67. Liu Y, Jiang TT, Shi TY, Liu YN, Liu XM, Xu GJ, Li FL, Wang YL, Wu XY. The effectiveness of diaphragmatic breathing relaxation training for improving sleep quality among nursing staff during the COVID-19 outbreak: a before and after study. Sleep Med. 2021;78:8-14. https://doi.org/10.1016/j.sleep.2020.12.003.

68. Qi J, Xu J, Li BZ, Huang JS, Yang Y, Zhang ZT, Yao DA, Liu QH, Jia M, Gong DK, Ni XH, Zhang QM, Shang FR, Xiong N, Zhu CL, Wang T, Zhang X. The evaluation of sleep disturbances for Chinese frontline medical workers under the outbreak of COVID19. Sleep Med. 2020;72:1-4. https://doi.org/10.1016/j.sleep.2020. 05.023 .

69. Şahin MK, Aker S, Şahin G, Karabekiroğlu A. Prevalence of depression, anxiety, distress and insomnia and related factors in healthcare workers during COVID-19 pandemic in Turkey. $\mathrm{J}$ 
Community Health. 2020;45(6):1168-77. https://doi.org/10.1007/ s10900-020-00921-w.

70. Stojanov J, Malobabic M, Stanojevic G, Stevic M, Milosevic V, Stojanov A. Quality of sleep and health-related quality of life among health care professionals treating patients with coronavirus disease-19. Int J Soc Psychiatry. 2020;16:20764020942800. https://doi.org/10.1177/0020764020942800.

71. Tu ZH, He JW, Zhou N. Sleep quality and mood symptoms in conscripted frontline nurse in Wuhan, China during COVID19 outbreak: a cross-sectional study. Medicine (Baltimore). 2020;99(26):e20769. https://doi.org/10.1097/MD.0000000000 020769.

72. Wang LQ, Zhang M, Liu GM, Nan SY, Li T, Xu L, Xue Y, Zhang M, Wang L, Qu YD, Liu F. Psychological impact of coronavirus disease (2019) (COVID-19) epidemic on medical staff in different posts in China: a multicenter study. J Psychiatr Res. 2020;129:198-205. https://doi.org/10.1016/j.jpsychires.2020. 07.008 .

73. Wang W, Song W, Xia Z, He Y, Tang L, Hou J, Lei S. Sleep disturbance and psychological profiles of medical staff and nonmedical staff during the early outbreak of COVID-19 in Hubei Province, China. Front Psychiatry. 2020;11:733. https://doi.org/ 10.3389/fpsyt.2020.00733.

74. Wu K, Wei X. Analysis of psychological and sleep status and exercise rehabilitation of front-line clinical staff in the fight against COVID-19 in China. Med Sci Monit Basic Res. 2020;26:e924085. https://doi.org/10.12659/MSMBR.924085.

75. Xiao H, Zhang Y, Kong D, Li S, Yang N. The effects of social support on sleep quality of medical staff treating patients with coronavirus disease 2019 (COVID-19) in January and February 2020 in China. Med Sci Monit. 2020;26:e923549. https://doi. org/10.12659/MSM.923549.

76. Zhan Y, Liu Y, Liu H, Li M, Shen Y, Gui L, Zhang J, Luo Z, Tao X, Yu J. Factors associated with insomnia among Chinese front-line nurses fighting against COVID-19 in Wuhan: a crosssectional survey. J Nurs Manag. 2020;28(7):1525-35. https:// doi.org/10.1111/jonm.13094.

77. Zhang C, Yang L, Liu S, Ma S, Wang Y, Cai Z, Du H, Li R, Kang L, Su M, Zhang J, Liu Z, Zhang B. Survey of insomnia and related social psychological factors among medical staff involved in the 2019 novel coronavirus disease outbreak. Front Psychiatry. 2020;11:306. https://doi.org/10.3389/fpsyt.2020. 00306.

78. Zhang H, Shi Y, Jing P, Zhan P, Fang Y, Wang F. Posttraumatic stress disorder symptoms in healthcare workers after the peak of the COVID-19 outbreak: a survey of a large tertiary care hospital in Wuhan. Psychiatry Res. 2020;294:113541. https://doi.org/10. 1016/j.psychres.2020.113541.

79. Zhou Y, Wang W, Sun Y, Qian W, Liu Z, Wang R, Qi L, Yang J, Song X, Zhou X, Zeng L, Liu T, Li Z, Zhang X. The prevalence and risk factors of psychological disturbances of frontline medical staff in china under the COVID-19 epidemic: workload should be concerned. J Affect Disord. 2020;277:510-4. https://doi.org/10. 1016/j.jad.2020.08.059.

80. Zhuo K, Gao C, Wang X, Zhang C, Wang Z. Stress and sleep: a survey based on wearable sleep trackers among medical and nursing staff in Wuhan during the COVID-19 pandemic. Gen Psychiatr. 2020;33(3):e100260. https://doi.org/10.1136/gpsych2020-100260.Erratum.In:GenPsychiatr.2020;33(4):e100260corr1.
81. Mong JA, Cusmano DM. Sex differences in sleep: impact of biological sex and sex steroids. Philos Trans R Soc Lond B Biol Sci. 2016;371(1688):20150110. https://doi.org/10.1098/rstb.2015. 0110.

82. Mallampalli MP, Carter CL. Exploring sex and gender differences in sleep health: a Society for Women's Health Research Report. J Womens Health (Larchmt). 2014;23(7):553-62. https://doi.org/ 10.1089/jwh.2014.4816.

83. Smolensky MH, Reinberg AE, Sackett-Lundeen L. Perspectives on the relevance of the circadian time structure to workplace threshold limit values and employee biological monitoring. Chronobiol Int. 2017;34(10):1439-64. https://doi.org/10.1080/ 07420528.2017.1384740.

84. Crigna AT, Samec M, Koklesova L, Liskova A, Giordano FA, Kubatka P, Golubnitschaja O. Cell-free nucleic acid patterns in disease prediction and monitoring-hype or hope? EPMA J. 2020;11(4):1-25. https://doi.org/10.1007/s13167-020-00226-x.

85. Kunin A, Sargheini N, Birkenbihl C, Moiseeva N, Fröhlich H, Golubnitschaja O. Voice perturbations under the stress overload in young individuals: phenotyping and suboptimal health as predictors for cascading pathologies. EPMA J. 2020;11(4):1-11. https:// doi.org/10.1007/s13167-020-00229-8.

86. Partinen M, Bjorvatn B, Holzinger B, Chung F, Penzel T, Espie CA, Morin CM. ICOSS-collaboration group: sleep and circadian problems during the coronavirus disease 2019 (COVID-19) pandemic: the International COVID-19 Sleep Study (ICOSS). J Sleep Res. 2021;30(1):e13206. https://doi.org/10.1111/jsr.13206.

87. Peter L, Reindl R, Zauter S, Hillemacher T, Richter K. Effectiveness of an online CBT-I intervention and a face-to-face treatment for shift work sleep disorder: a comparison of sleep diary data. Int J Environ Res Public Health. 2019;16(17):3081. https://doi.org/ 10.3390/ijerph16173081.

88. Marouf N, Cai W, Said KN, Daas H, Diab H, Chinta VR, Hssain AA, Nicolau B, Sanz M, Tamimi F. Association between periodontitis and severity of COVID-19 infection: a case-control study. J Clin Periodontol. 2021. https://doi.org/10.1111/jcpe.13435.

89. Koklesova L, Samec M, Liskova A, Zhai K, Büsselberg D, Giordano FA, Kubatka P, Golunitschaja O. Mitochondrial impairments in aetiopathology of multifactorial diseases: common origin but individual outcomes in context of 3P medicine. EPMA J. 2021;12(1):1-14. https://doi.org/10.1007/s13167-021-00237-2.

90. Skladany L, Koller T, Adamcova Selcanova S, Vnencakova J, Jancekova D, Durajova V, Laffers L, Svac J, Janickova K, Palkovič M, Kohout P, Golubnitschaja O. Challenging management of severe chronic disorders in acute pandemic situation: chronic liver disease under COVID-19 pandemic as the proof-of-principle model to orchestrate the measures in 3PM context. EPMA J. 2021;12(1):1-14. https://doi.org/10.1007/s13167-021-00231-8.

91. Zharinov GM, Bogomolov OA, Chepurnaya IV, Neklasova NY, Anisimov VN. Melatonin increases overall survival of prostate cancer patients with poor prognosis after combined hormone radiation treatment. Oncotarget. 2020;11(41):3723-9. https://doi.org/ 10.18632/oncotarget.27757.

Publisher's note Springer Nature remains neutral with regard to jurisdictional claims in published maps and institutional affiliations. 